\title{
Study on Factors Influencing Production Cost of Prefabricated Components Based on AHP
}

\author{
LU Wenbin ${ }^{1}$ \\ ${ }^{1}$ School of Economics and Management, Beijing Jiaotong University Beijing, China
}

\begin{abstract}
Because of the high cost, the development of prefabricated buildings in China is slow. As a significant part of the total cost of prefabricated buildings, the cost of prefabricated components has a great impact on the total cost. In this paper, the influencing factors of component production cost are analyzed in detail from five aspects of labor cost, material cost, machinery cost, external environment condition and internal production management arrangement, and the index system of influencing factors of production cost is constructed. Using the analytic hierarchy process model, the influencing factors are determined as: material cost $>$ labor cost $>$ machinery cost $>$ internal production and management arrangement $>$ external environment condition, and then it is put forward Corresponding cost control measures for component production.
\end{abstract}

\section{Introduction}

China began to develop prefabricated buildings in the 1950 s, but due to various reasons, they have not been fully developed. The Ministry ${ }^{[1]}$ of housing and urban rural development pointed out in the outline for the modernization development of construction industry that by 2025 , the prefabricated building area will account for more than $50 \%$ of the new building area. As a result, the development of prefabricated buildings in China has entered a new stage, but due to the high production cost of prefabricated components, the development speed of prefabricated buildings is slow. Therefore, the effective control of component production cost can not only reduce the total cost of the project, but also promote the development of prefabricated buildings in China.

Domestic scholars began to study the prefabricated buildings. Guo Dekun ${ }^{[2]}$ analyzed the impact of design cost and construction period shortening on capital cost from the perspective of design advantage. Wen Min [3] from the perspective of the construction unit, combined with the theory of project cost risk management and the actual project case analysis. Liu Chunmei ${ }^{[4]}$ mainly analyzes the cost composition of cast-in-place shear wall structure and prefabricated shear wall structure. Chang Chunguang $^{[5]}$ analyzes the reasons for the high cost of component production from the perspective of component processing drawing design, mold design, production and use. Sun Luyan ${ }^{[6]}$ and others analyzed the influencing factors of component production cost from component design stage, mold configuration and production management, and thought that PC component in-depth design was the main reason of high component production cost.

The existing research on assembly project has gradually transferred from the total cost of assembly building to the production cost of prefabricated components, but the research on cost control from the perspective of component production is relatively few. Therefore, this paper analyzes the component production cost from the perspective of the influencing factors of component production cost, establishes the analytic hierarchy process model, determines the weight of each influencing index, and puts forward the measures to control the component production cost.

\section{Analysis of Factors Influencing the Production Cost of Components}

The production cost of prefabricated concrete components can be defined as the sum of the prices of labor, materials, machinery and other production factors invested in the production process of prefabricated concrete components. Based on the definition of component production cost and production process, this paper points out that the factors influencing the production cost of prefabricated concrete components are composed of five parts, including labor cost, material cost, machinery cost, external environmental conditions (including policy conditions, taxes and fees, site planning of the factory) and internal production and management arrangements (including production scale, component output and personnel incentive party).

\subsection{Labor Cost}

The main factors affecting labor cost are the number of production personnel, salary level, personnel quality, etc.. Compared with the traditional cast-in-place components, the construction cost of prefabricated components is $106 \%$ 
more than that of the traditional cast-in-place components, but the labor cost is reduced. If cast-in-place components are combined with prefabricated components, the labor cost can be reduced by $42.5 \%$. Therefore, determining the proportion of cast-in-place and assembly, determining the reasonable prefabrication rate has a great impact on the labor cost. Based on the analysis of the proportion of labor cost in the three construction modes, the proportion of labor cost in the production cost of components is more than $20 \%$, which shows that labor cost is still an important factor in the production cost of components.

\subsection{Material Cost}

The production of prefabricated components requires raw materials such as steel bars, cement, sand, stones, molds, etc., so the material cost needs to consider the supply price of raw materials, purchase and storage cost of raw materials, transportation and miscellaneous cost of raw materials, transportation and consumption cost of raw materials, mold consumption cost, etc. Based on the analysis of practical examples and the current specifications, Qiang Xuyuan ${ }^{[7]}$ concluded that compared with cast-in-place production of fabricated components, there is an increase in concrete and reinforcement.

The price of raw material supply is mainly affected by the market, suppliers and buyers. Raw material purchase and storage fees usually consider a series of handling fees in the purchase process, as well as storage fees and storage fees after the materials enter the site. The transportation and miscellaneous expenses and transportation consumption expenses of raw materials mainly consider the transportation and loading and unloading expenses of materials transported from the delivery place to the warehouse of the processing plant, the insurance expenses during the transportation of goods, the handling fees of the equipment supply and marketing department, and the transportation consumption expenses due to the change of environmental conditions or uncontrollable factors during the transportation of materials.

Mold consumption cost refers to the cost of concrete pouring when the component is in production. Every assembly and disassembly may have a great impact on the mold, resulting in mold loss, which needs to be included in the production cost of components.

\subsection{Machinery Cost}

The production of prefabricated components requires expensive mechanical equipment. From the purchase of mechanical equipment to the putting into use of mechanical equipment, there are many links that produce costs, such as the purchase cost of mechanical equipment, wear cost, maintenance cost, power fuel cost, etc.

The purchase cost of mechanical equipment is mainly composed of the original price of the equipment and freight and miscellaneous charges. The import equipment also needs to consider the tariff and customs fees. The price of special mechanical equipment is generally high, so the purchase cost of mechanical equipment has become an important part affecting the production cost of components. During the production of components, the wear and maintenance expenses of mechanical equipment will be amortized to the cost of unit product in the form of depreciation and amortization expenses of fixed assets. Power fuel cost refers to water and electricity cost, oil and gas fuel cost, etc. The type of equipment and fuel shall be considered for the power fuel cost. The energy consumption of different types of mechanical equipment is different, and the price of different fuel types is also different, such as the price of hydropower, gasoline and diesel.

\subsection{External Environmental Conditions}

The influencing factors of component production cost need to consider the policy conditions, taxes and the site planning of the factory. The site planning of the factory generally includes the site selection, plane layout and site layout of the factory. Once the location of the plant is established, it is generally not to be relocated, so the layout of the plant area and the layout of the production site are mainly considered. The plane layout of the plant area, which layout form is selected, and the cost of different layout ways is different. According to the production process of components, corresponding stacking area, processing area, maintenance area, etc. need to be divided. Such complex site layout and site planning will have an impact on the production cost.

\subsection{Internal Production Management Arrangement}

The arrangement of internal production management mainly refers to some measures taken by component manufacturers for component production, including production scale, component output, personnel incentive mode, performance appraisal, etc. Component production cost can be divided into fixed cost and variable cost, in which fixed cost refers to the part not affected by production, which usually refers to the depreciation and amortization of plant and mechanical equipment. The change of component production scale and component output will lead to the change of production cost. Its impact on cost is mainly reflected in the allocation of fixed cost. Increasing output will make the fixed cost allocated to more unit products. However, the impact of personnel incentive mode and performance appraisal on cost is reflected in labor productivity. A reasonable incentive system can promote production enthusiasm, speed up production efficiency, increase production, and then reduce costs.

\section{Construction and Analysis of AHP}

\subsection{Build Index System}

In the process of index construction, this paper comprehensively considers the component production cost composition, influencing factors and the expenses of each production process, draws many experts' views on 
the impact index of the assembly component production cost, combines the actual production situation, adopts the experience determination method and the checklist method, and obtains the corresponding index group, and constructs the index system(shown in Table 1).

TABLE 1. Production cost impact index system of prefabricated concrete components

\begin{tabular}{|c|c|c|}
\hline Target layer & Criteria layer & Scheme layer \\
\hline \multirow{18}{*}{$\begin{array}{l}\text { Factors } \\
\text { influencing } \\
\text { the } \\
\text { production } \\
\text { cost of } \\
\text { prefabricat- } \\
\text { ed concrete } \\
\text { component- } \\
\text { s A }\end{array}$} & \multirow{3}{*}{ Labor cost B1 } & $\begin{array}{l}\text { Number of production personnel } \\
\mathrm{C} 1\end{array}$ \\
\hline & & $\begin{array}{c}\text { Salary level of production } \\
\text { personnel C2 }\end{array}$ \\
\hline & & Quality of production personnel C3 \\
\hline & \multirow{5}{*}{$\begin{array}{l}\text { Material cost } \\
\quad \text { B2 }\end{array}$} & Raw material supply price $\mathrm{C} 4$ \\
\hline & & $\begin{array}{l}\text { Raw material purchase and storage } \\
\text { price C5 }\end{array}$ \\
\hline & & $\begin{array}{c}\text { Transportation and miscellaneous } \\
\text { cost of raw materials C6 }\end{array}$ \\
\hline & & $\begin{array}{c}\text { Cost of raw material transportation } \\
\text { and consumption } \mathrm{C} 7\end{array}$ \\
\hline & & Mold consumption costC 8 \\
\hline & \multirow{4}{*}{$\begin{array}{l}\text { Machinery } \\
\text { cost B3 }\end{array}$} & $\begin{array}{c}\text { Purchase cost of mechanical } \\
\text { equipment C9 }\end{array}$ \\
\hline & & $\begin{array}{c}\text { Wear and tear cost of mechanical } \\
\text { equipment } \mathrm{C} 10\end{array}$ \\
\hline & & $\begin{array}{c}\text { Maintenance cost of mechanical } \\
\text { equipment } \mathrm{C} 11\end{array}$ \\
\hline & & Power fuel cost $\mathrm{C} 12$ \\
\hline & \multirow{3}{*}{$\begin{array}{c}\text { External } \\
\text { Environmental } \\
\text { Conditions B4 }\end{array}$} & Policy C13 \\
\hline & & Site planning of the plant $\mathrm{C} 14$ \\
\hline & & $\begin{array}{l}\text { taxes and administrative charges } \\
\text { C15 }\end{array}$ \\
\hline & \multirow{3}{*}{$\begin{array}{c}\text { Internal } \\
\text { Production } \\
\text { Management } \\
\text { Arrangement } \\
\text { B5 }\end{array}$} & Production scale $\mathrm{C} 16$ \\
\hline & & Component Yield C17 \\
\hline & & Personnel incentive mode $\mathrm{C} 18$ \\
\hline
\end{tabular}

According to the influence index model of production cost of prefabricated concrete components determined by experience determination method and checklist method, the experts are graded by questionnaire. The questionnaire is distributed to experts engaged in assembly construction or front-line personnel engaged in the field of engineering projects. Comprehensive sorting out the scores of the recovered questionnaire, listing the corresponding impact index judgment matrix, and then calculating the single level weight and combined weight of the impact index.

\subsection{Weight calculation and analysis of influencing factors}

According to the model calculation, after determining the influence factor weights of the criteria layer and the scheme layer, calculate the combined weights, make the overall arrangement of the levels, and all pass the consistency test (shown in Table 2).

$$
\begin{aligned}
\omega_{i} & =\overline{\omega_{i}} / \sum_{j=1}^{n} \overline{\omega_{j}} \\
\overline{\omega_{i}} & =\sqrt[n]{m_{i}}
\end{aligned}
$$

\begin{tabular}{|c|c|c|c|c|}
\hline $\begin{array}{c}\text { Criteria } \\
\text { layer }\end{array}$ & $\begin{array}{l}\text { Scheme } \\
\text { layer }\end{array}$ & Weight & $\begin{array}{c}\text { Combined } \\
\text { weight }\end{array}$ & $\begin{array}{l}\text { Total } \\
\text { order }\end{array}$ \\
\hline \multirow{3}{*}{ B1 } & $\mathrm{C} 1$ & \multirow{3}{*}{0.327} & 0.208 & 2 \\
\hline & $\mathrm{C} 2$ & & 0.084 & 3 \\
\hline & $\mathrm{C} 3$ & & 0.034 & 8 \\
\hline \multirow{5}{*}{ B2 } & $\mathrm{C} 4$ & \multirow{5}{*}{0.432} & 0.226 & 1 \\
\hline & $\mathrm{C} 5$ & & 0.073 & 5 \\
\hline & C6 & & 0.033 & 9 \\
\hline & C7 & & 0.028 & 11 \\
\hline & $\mathrm{C} 8$ & & 0.073 & 6 \\
\hline \multirow{4}{*}{ B3 } & C9 & \multirow{4}{*}{0.117} & 0.073 & 4 \\
\hline & $\mathrm{C} 10$ & & 0.013 & 14 \\
\hline & C11 & & 0.007 & 18 \\
\hline & $\mathrm{C} 12$ & & 0.023 & 12 \\
\hline \multirow{3}{*}{ B4 } & C13 & \multirow{3}{*}{0.048} & 0.007 & 17 \\
\hline & C14 & & 0.009 & 15 \\
\hline & $\mathrm{C} 15$ & & 0.032 & 10 \\
\hline \multirow{3}{*}{ B5 } & C16 & \multirow{3}{*}{0.075} & 0.019 & 13 \\
\hline & $\mathrm{C} 17$ & & 0.048 & 7 \\
\hline & $\mathrm{C} 18$ & & 0.008 & 16 \\
\hline
\end{tabular}

TABLE 2. Total ranking of weight of each influencing factor

According to the total ranking results of weight, among the influencing factors of component production cost, material cost accounts for the highest proportion (43.2\%), followed by labor cost $(32.7 \%)$, and machinery cost $(11.7 \%)$. Therefore, the production cost of prefabricated concrete components should be controlled from three aspects: material cost, labor cost and machinery cost, and the most important one is to strengthen the control of material cost and labor cost.

\section{Production Cost Control Measures}

\subsection{Material Cost Control}

On the one hand, control the purchase price of materials. In the selection of suppliers, select suppliers with price advantage to establish close cooperation with them, so as to ensure that the supply of raw materials is less affected by market price fluctuations. On the other hand, controlling the material purchase quantity, makes the material consumption account and reduces the storage cost. In the production process, establish a perfect material requisition system to ensure that production personnel form a sense of saving, strictly regulate production, reduce material waste to control costs. At the same time, optimize the mold design and production to achieve large-scale production. By reducing the weight of the mold, reducing the time consumption of mold assembly and removal, and 
improving the efficiency.

\subsection{Labor Cost Control}

Improve the standardization rate of prefabricated components, reduce manual operation, realize large-scale mechanized production, and reduce the number of production personnel. Arrange processing schedule reasonably and make full use of flow production. Reasonably adjust the operation time of each process, such as arranging pouring in the daytime and maintenance at night. At the same time of standardizing the working procedure operation time, arrange the flow production, reduce the labor intensity of workers, improve the labor productivity, and speed up the production of components.

Strengthen staff management and assessment. For the technical old employees and business backbones of the enterprise, the salary level should be guaranteed to ensure their stability; for the short-term employees and temporary workers, the management should be strengthened to advocate one specialty and multiple abilities. In the performance appraisal, the employees with excellent performance and high working efficiency should be given material rewards to promote their enthusiasm for production; for the employees with poor performance and low enthusiasm for work, measures such as dismissing or reducing their salary level can be taken to ensure production efficiency. Through flexible labor regulation and reward and punishment system, the production efficiency can be guaranteed, so as to indirectly realize the control of labor cost.

\subsection{Machinery Cost Control}

On the one hand, reasonable procurement form, domestic and high versatility equipment shall be adopted to reduce other expenses in the procurement process. Through bidding procurement, fully understand the equipment parameters and quality conditions that can be provided by each bidding unit, and select suppliers with price and quality advantages. Try to purchase domestic equipment and reduce customs duties and customs supervision fees. On the other hand, strengthen the maintenance of mechanical equipment, reduce the wear and maintenance costs of machinery, improve the service life of machinery, improve the operation skills of employees, reduce the phenomenon of artificial parking and long-term idling of machinery. Through the cultivation of the sense of responsibility of employees and the enhancement of performance evaluation, restrict the behavior of employees for parking, and ensure the production efficiency.

\section{Conclusion}

The production cost of prefabricated components accounts for $84 \%$, while the installation cost only accounts for $16 \%$. Reducing the production cost of components plays a key role in the total cost control of prefabricated buildings. Through the analytic hierarchy process model, the influencing factors of component production cost are determined as follows: material cost $>$ labor cost $>$ machinery cost $>$ internal production and management arrangement $>$ external environmental conditions; the most important influencing factors of material cost are the supply price of raw materials; the most important influencing factors of labor cost are the number of production personnel; the most important influencing factors of machinery cost are the purchase of machinery and equipment Fee. Therefore, the production cost of control components can be controlled from the perspective of material cost, labor cost and machinery cost.

\section{Acknowledgement}

In the empirical research part of this article, the expert scoring method is used to score and compare various influencing factors. I'd like to thank all the experts for their valuable opinions on this article.

\section{References}

1. Ministry of housing and urban rural development, outline of modernization development of construction industry, 2015.

2. Guo Dekun. Scheme and cost analysis of prefabricated buildings [D]. Zhengzhou University, 2017.

3. Wen min. Application Research on cost risk management of prefabricated concrete residential buildings [D]. Hunan Agricultural University, 2016.

4. Liu Chunmei. Construction cost analysis and control of prefabricated concrete buildings [D]. Liaocheng University, 2016.

5. Chang Chunguang. Study on production cost control of prefabricated building components and measures [J]. Journal of Shenyang Jianzhu University (Social Science Edition), 2016, pp. 471-472.

6. Sun Luyan, Liu Honglu, Zhao Feifei. Analysis of PC component production cost management and control [J]. Building materials technology and application, 2019, p. 36.

7. Qiang Xuyuan. Incremental cost analysis of assembly integrated structure [J]. Concrete world, 2018, p.32. 